\title{
An unconventional but prudent proposal for China's democratisation
}

\author{
Jiwei Ci: Democracy in China: The Coming Crisis. Harvard University \\ Press, Cambridge, MA, 2019, 420 pp, ISBN: 978-0674238183
}

\section{Yu-Wen Chen ${ }^{1,2}$}

Published online: 31 March 2020

(c) The Author(s) 2020

Democracy in China: The Coming Crisis is an unconventional book that argues that China already has a democratic society without a democratic political reality, and, hence, it is necessary for the Chinese Communist Party (CCP) to prepare itself for democracy before it is too late. Written by Jiwei Ci, Professor of Philosophy at the University of Hong Kong, the book contains many references to western philosophers' musings on democracy and its various related concepts. At first glance, readers might find the book rather normative, as the author strives to argue for a democratic necessity, as well as the preparation for it, in China. But $\mathrm{Ci}$ explains that his ultimate goal is not to make a normative argument but rather a prudential one to highlight that China has no choice but to prepare itself for democracy.

Ci's argument is at loggerheads with a rising body of the literature, written by various China observers and political scientists in recent years, defending the focus of the Chinese way of development on meritocracy, rather than on a western form of liberal democracy. Meritocracy is deeply rooted in traditional Confucian values. Western scholars, such as Bell (2015), and Chinese scholars, such as Zhang (2012), have unabashedly suggested that meritocracy has worked well to ensure the performance legitimacy of the ruling CCP and, thus, provides a viable alternative to western democracy. Hence, the chances of China transforming itself into a democracy are low.

For centuries, whichever regime was in charge of Confucian China drew greatly upon an unknown natural legitimacy "from heaven" to justify its existence. Mao's China, and the CCP thereafter, initially drew upon a revolutionary aura to legitimise its existence. As both heavenly legitimacy and revolutionary legitimacy run thin in contemporary China, the reliance on performance legitimacy has become crucial

Yu-Wen Chen

julie.chen@helsinki.fi

1 University of Helsinki, Helsinki, Finland

2 Palacky University, Olomouc, Czech Republic 
to the CCP's rule. Ci differs from the aforementioned scholars by arguing that the CCP's (over-) reliance on performance legitimacy poses a threat to the party's ruling legitimacy. As any China expert knows, the Chinese party-state has made sure that whenever we talk about the economy in China, we talk about politics. The economy is predominantly steered by political orders from above, despite the fact that local governments and actors also share some diluted power in policy implementation. However, when the Chinese economy does not fare well-and this will likely happen in the coming decade- $\mathrm{Ci}$ believes that the $\mathrm{CCP}$ will need to develop a new, more solid form of legitimacy for the party to sustain itself.

In Ci's view, the China of today is already more prepared to embrace democracy than the China of the past. The reason for this is the higher quality of life and advancement of various socioeconomic conditions that have elevated people to enjoy a much more equal condition for development than before. Chinese society is vibrantly developing conditions that can already be considered facets of a democratic society. Ci calls such social conditions "substantive populism", which makes democracy a partial reality in China. In time, this partial reality will become a complete reality. Although there are currently few proper democratic procedures at the political level, societal democracy will eventually sow the seeds for political democracy.

$\mathrm{Ci}$ recognises that present-day China, under Xi Jinping's rule, is suppressed in various domains. However, he argues that the more the regime suppresses Chinese society, the more one can conclude that it is indeed a democracy. The main challenge for the CCP now is to stop denying the existence of political democracy. Ci points out that there is already a mention of the term democracy in the party's core values, regardless of the fact that the term has a different meaning to the same term used in the west. It is true that even the Chinese Constitution mentions the "democratic dictatorship" of the party. However, this term in practice means dictatorship and has nothing to do with western notions of democracy. $\mathrm{Ci}$ contends that even if the term is mistakenly used in various CCP documents, it shows that the party understands that it cannot legitimise itself without using the term democracy. Ultimately, in Ci's vision, the CCP will need to take a bold decision to consider prudent and gradual democratic reform in order to maintain its legitimacy. Hence, Ci's understanding of the coming of democracy is formed by his view that Chinese society presents a fertile ground for it. The key is that people in the upper echelons of the CCP will have to accept the fact that it is better to start democratic reform than not to. Differing from some popular political observers' predictions that democracy might split China and cause instability, Ci's prudent arguments support a democratic China that is capable of keeping the country unified and stable and maintaining its sovereignty.

This book might not be the book of choice for many empirically based political scientists because a lot of the ideas proposed by the author are not supported by solid empirical data. For instance, even though Chinese society is vibrant and diverse, the claim that it is already a societal democracy counters many empirical observations. However, Harvard University Press has been bold to support this book because, in my opinion, there is a need to think beyond what currently appears sensible to China watchers and imagine a scenario where China will democratise, not in a chaotic manner (which many have predicted) but in a prudent, mature and 
prosperous way. This book provides the most sophisticated arguments and scenarios in support of that day happening.

Open Access This article is licensed under a Creative Commons Attribution 4.0 International License, which permits use, sharing, adaptation, distribution and reproduction in any medium or format, as long as you give appropriate credit to the original author(s) and the source, provide a link to the Creative Commons licence, and indicate if changes were made. The images or other third party material in this article are included in the article's Creative Commons licence, unless indicated otherwise in a credit line to the material. If material is not included in the article's Creative Commons licence and your intended use is not permitted by statutory regulation or exceeds the permitted use, you will need to obtain permission directly from the copyright holder. To view a copy of this licence, visit http://creativecommons.org/licen ses/by/4.0/.

\section{References}

Bell, D. 2015. The China Model: Political Meritocracy and the Limits of Democracy. Princeton: Princeton University Press.

Zhang, W. 2012. The China Wave: Rise of a Civilizational State. Singapore: World Scientific Publishing.

Publisher's Note Springer Nature remains neutral with regard to jurisdictional claims in published maps and institutional affiliations.

Yu-Wen Chen is Professor of Chinese Studies at the Department of Cultures at the University of Helsinki and Hosting Professor at the Department of Asian Studies at Palacky University in Czech Republic. 